\title{
KONDISI PSIKOLOGI MEMPENGARUHI PRODUKSI ASI IBU MENYUSUI DI BPS ASKI PAKIS SIDO KUMPUL SURABAYA
}

\author{
Nurul Kamariyah \\ (UNUSA, FIK, Prodi SI Keperawatan - J1. Smea 57 Surabaya) \\ email:kamariyahnurul@ymail.com
}

\begin{abstract}
In postpartum period, the maternal psychological condition is often accompanied by the problems which may affect the breast milk production. The postpartum anxiety can become one of the factors which influences the breast milk production. Therefore, the purpose of this study was to analyze the relationship between breast milk production and the smoothness of breast milk production at BPS ASKI (Private Maternity Clinic) located on Pakis Sido Kumpul, Surabaya. The design of analytic-cross sectional. The population 19 primiparous mothers. The simple random sampling technique was used to take 18 respondents. The independent variable of the study was the maternal psychological condition, whereas the dependent one was the smoothness of breast milk production. Questionnaires (in checklist form) and observation sheets were used to collect the data, which were then analyzed by using ChiSquare statistic test with the significance level $\alpha=0.05$. The result of study showed that most of the respondents $(61.1 \%)$ had psychological problems, whereas most of them $(72.2 \%)$ also experienced the smoothness of breast milk production. The result $\mathrm{p}=0.001$; it meant that $\mathrm{p}<\alpha$ so that $\mathrm{H}_{0}$ was rejected describing that there was a relationship between breast milk production and the smoothness of breast milk production at BPS ASKI (Private Maternity Clinic) located on Pakis Sido Kumpul, Surabaya. In conclusion, the better maternal psychological condition would bring effects on the better breast milk production.
\end{abstract}

\begin{abstract}
Abstrak: Kondisi psikologis ibu setelah melahirkan sering mengalami gangguan, yang akan berpengaruh pada produksi ASI. Masalah ini bisa terjadi karena adanya masa transisi menjadi orang tua, kecemasan saat post partum yang dirasakan dapat menjadi salah satu faktor mempengaruhi produksi ASI. Tujuan penelitian ini untuk menganalisis hubungan antara kondisi psikologis ibu dengan kelancaran produksi ASI di BPS ASKI Pakis Sido Kumpul Surabaya. Desain analitik korelasi dengan pendekatan cross sectional. Populasi sebesar 19 orang, teknik sampling adalah sampel random sampling, dan besar sampel sebesar 18 responden. Alat pengumpulan data dengan kuisioner bentuk chek list dan lembar observasi. Variabel independen kondisi psikologis ibu dan variabel independen kelancaran produksi ASI. Data dianalisis menggunnakan uji statistik chi-square. Dengan tingkat kemaknaan $\alpha=$ $<0,005$. Hasil penelitian menunjukan sebagian besar $(61,1 \%)$ ibu mengalami gangguan psikologis dan sebagian besar $(72,2 \%)$ ketidaklancaran pada ASI. Hasil $=0,001$ artinya $<\alpha=0,05$ maka $\mathrm{H} 0$ ditolak yaitu ada hubungan antara kondisi psikologis ibu dengan kelancaran produksi ASI. Semakin baik kondisi psikologis ibu melahirkan semakin baik pula produksi ASInya.
\end{abstract}

Kata kunci : psikologi, produksi ASI 


\section{PENDAHULUAN}

ASI merupakan salah satu sumber makanan yang terbaik bagi bayi yang baru lahir karena memiliki bagitu banyak zat penting guna meningkatkan kekebalan terhadap penyakit. Makanan bayi dan susu yang dibuat dengan tegnologi masa kini mampu mengantikan sumber makanan yang menajubkan ini. (Kodrat, 2010).

Pemberian asupan ASI setelah melahirkan bisa menjadi proses yang tidak mudah bagi seorang ibu, dikarenakan ibu pada masa menyusui merupakan masa yang paling sensitif baik dalam kehidupan ibu secara fisik atau emosional. Sebagian besar ibu di BPS ASKI Pakis Sido Kumpul Surabaya pada waktu menyusui yang mengalami kegelisahan, kecemasan dan ketidaknyamanan secara psikologis dengan kelahiran anak, sering atau banyak juga ibu yang kurang pengetahuan tentang faktor yang dapat mempengaruhi kelancaran produksi ASI, dampak psikologis terdapat kelancaran produksi ASI, ibu merasa pesimistis mengenai jumlah yang dihasilkan. Masalah seperti ini sering dijumpai pada ibu masa postpartum, kekecewaan ini bisa terjadi karena adanya masa transisi menajadi orang tua, kecemasan saat postpartum yang dirasakan dapat menjadi salah satu faktor mempengaruhi kelancaran produksi ASI, kecemasan itu sendiri mulai timbul ketika individu menghadapi pengalaman-pengalaman baru dimulainya dari kehamilan, proses melahirkan dan setelah melahirkan. (Stuart \& Sundeen,1993 dikutip dalam pratiwi, 2010).

Hasil penelitian Iin Febriana tahun 2010, dengan judul hubungan tingkat kecemasan pada primipara dengan kelancaran ASI dipuskesmas kecamatan Lubuk Kalingan Surabaya, didapatkan data ibu yang mengalami gangguan psikologis atau kecemasan ringan sebanyak $73, \quad 3 \%$ dan $66,7 \%$ mengalami produksi ASI yang tidak lancar.

Faktor mental dan psikologis ibu menyusui sangat besar pengaruhnya terhadap proses menyusui dan kelancaran produksi ASI. Persaan stress, tertekan, dan tidak nyaman yang dialami oleh seorang ibu dapat menghabat jumlah ASI yang keluar (Bahayatun, 2009). Menurut penelitian (Sholihah, at al, 2010) menyebutkan bahwa ibu yang mendapatkan dukungan dari suami atau keluarga sebanyak 53,3\% sedangkan ibu yang tidak mendapatkan dukungan dari suami sebanyak 44,4\%. Hal ini menunjukan bahwa keputusan seorang ibu untuk menyusui membutuhkan dukungan suami dan keluarga. Berdasarkan hasil studi pendahuluan pada tanggal 12 - 17 November 2012 di BPS ASKI pada 10 ibu nifas terdapat 6 (60\%) ibu primipara yang merasakan kecemasan dan ketegangan setelah melahirkan dan 4 (40\%) ibu primipara tidak merasakan kecemasan. Ibu yang mengalami kelancaran produksi ASI adalah $50 \%$ dan yang tidak mengalami produksi ASI adalah $50 \%$.

Masa menyusui adalah masa yang paling sensitif dalam kehidupan ibu baik secara fisik maupun emosional. Kehadiran seorang bayi akan mengubah kehidupan ibu secara fisik, emosional dan psikologis. Tentu banyak hal yang harus dipersiapkan dan salah satu terpenting adalah pemberian ASI, karena dengan menyusui bayi berarti telah memberikan nutrisi penting, melindunginya dari penyakit dan infeksi dan yang terpenting adalah menjalin hubungan yang spesial dengan bayi. Sangat disayangkan, kadang muncul keluhan dan kesulitan menyusui, salah satunya dengan ASI yang tidak keluar lancar. Upaya yang dilakukan selain melatih bayi menyusu ibu harus mempersiapkan kondisi fisik dan mental seoptimal mungkin (Indriarti, 2006). Dalam proses menyusui seorang ibu dipengaruhi oleh 2 hormon yaitu prolaktin dan oksitosin. Menyusui sendiri 
mempunyai 2 arti yaitu produksi dan pengeluaran ASI. Proses produksi ASI dikenal sebagai hormonal.

Hormon prolaktin adalah hormon yang berperan dalam produksi ASI, karenanya produksi ASI akan terganggu jika ibu menyusui mengalami kegelisahan dan ketidaknyamanan secara psikologis. Keadaan psikologis ibu sangat berpengaruh terhadap kelancaran produksi ASI, keadaan ibu yang setelah melahirkan masih mengalami kesulitan untuk menyusui, bahkan beberapa penelitian menemukan bahwa ibu yang merasa pesimitis mengenai jumlah ASI yang dapat dihasilkanya ternyata benarbenar mengalami gangguan produksi ASI. Sebaliknya perasaan nyaman dan ada ikatan emosional antara ibu dan bayi saat proses menyusui, merangsang produksi ASI karena semakin sering menghisap payudara ibu, maka makin banyak ASI di produksi. Pengososngan payudarah semakin tuntas merangsang kerja hormon berkerja mengirim pesan ke otak bahwa jumlah ASI yang diproduksi habis terpakai atau dikeluarkan melalui isapan bayi sehingga ASI baru harus diproduksi lagi untuk memenuhi kebutuhan berikutnya. Selanjutnya, proses pengeluaran ASI atau pengosongan payudara secara umum akan mempengaruhi keberhasilan menyusui, hormon oksitosin berkerja memacu kontraksi atau otot agar ASI dapat di pompa keluar.(Februhartanty, 2009).

Proses produksi ASI juga di pengaruhi beberapa faktor diantaranya adalah faktor Nutrisi, perawatan payudara, faktor isapan bayi,faktor sosial budaya, faktor menyusui dan faktor psikologis. Faktor nutrisi ini perlu diperhatikan oleh seorang ibu dalam proses menyusui karena dalam menikatkan produksi ASI seorang ibu harus meningkatkan kebutuhan nutrisinya dengan cara meningkatkan prosi makan yang mengandung protein karena kandungan protein berfungsi untuk membentuk jaringan baru guna dalam produksi ASI. Faktor perawatan payudara juga sangat penting dalam dalam kelancaran ASI, apabila seorang ibu melakukan perawatan payudara dengan benar dan teratur dapat merangsang produksi ASI. Faktor isapan bayi yang berfungsi untuk merangsang hormon prolaktin sebagai produksi ASI semakin banyak dilakukan isapan semakin banyak susu yang akan diproduksi. Kemudian faktor sosisal budaya, terdapat adanya budaya-budaya terdapat dari masyarakat tentang menyusui serta mitos-mitos yang salah dalam menyusui dapat mempengaruhi ibu untuk berhenti menyusui. Faktor menyusui juga mempengaruhi semakin sering ibu menyusui dapat merangsang otot polos sesunanan saraf disekitarnya dan menerusakan rangsangan ke otak untuk memproduksi ASI. kemudian faktor psikologis di mana faktor ini sangat berpengaruh terhadap kelancaran produksi ASI, kondisi ibu yang tidak nyaman dan gelisah dapat menghambat produksi ASI. (Vivian, 2011).

Peran petugas kesehatan adalah memberikan pendidikan kesehatan dengan memberikan penyuluhan untuk memberikan dorongan kepada ibu dengan cara memberikan informasi tentang kelancaran air susu khusunya pengaruh dukungan sosial terhadap kelancaran produksi ASI, kemudian memberikan pengetahuan dengan cara pendidikan langsung kepada pasien, menyebarkan leaflet dan poster kepada masyarakat, serta melibatkan keluarga untuk memberikan dukungan kepada ibu menyusui untuk memberikan ASI.

\section{METODE PENELITIAN}

Desain penelitian yang digunakan adalah dengan pendekatan Cross Sectional karena mengamati variabel independen dan variabel dependen hanya satu kali dalam periode yang sama. Populasi dalam penelitian ini adalah semua ibu primipara yang melahirkan di 
BPS ASKI yang terletak di Pakis Sido Kumpul Surabaya, dengan besar populasi penelitian adalah 19 responden. Sampel sebesar 18 responden, sampling dilakukan menggunakan teknik Probability Sampling secara "Simple Random Sampling". Instrumen penelitian dengan menggunakan metode EPDS (Endinburgh Posnatal Depression Scale) yang sudah dimodifikasi oleh peneliti dari bentuk kuisioner menjadi chek list untuk mengali data tentang kondisi psikologis ibu dan lembar observasi untuk data kelancaran produksi ASI di BPS ASKI Pakis Sido Kumpul Surabaya.

Data yang diperoleh dari hasil pengamatan yang menggunakan lembar chek list untuk mendapatkan data psikologis ibu dan lembar observasi untuk memperoleh data kelancaran produksi ASI di BPS ASKI Surabaya. Pengolahan data dengan cara tabulasi silang dan menggunakan Chi-square $\left(\chi^{2}\right)$. dengan menggunakan SPSS for windows.

\section{HASIL PENELITIAN}

1) Karakteristrik responden menurut usia reproduksi

Tabel 5.1 Distribusi Frekuensi responden menurut usia reproduksi di BPS ASKI Pakis Sido Kumpul Surabaya 2013.

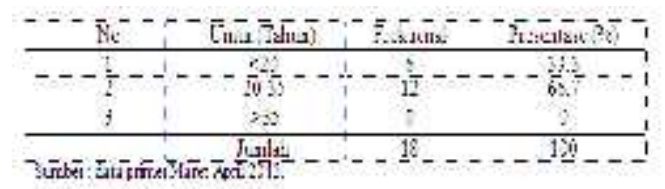

Berdasarkan tabel 5.1 dapat menunjukan dari 18 responden sebagian besar $(66,7 \%)$ berusia $20-35$ tahun.

2) Karasteristrik responden menurut pendidikan.

Tabel 5.2 Distribusi frekuensi responden menurut pendidikan di BPS ASKI Pakis Sido Kumpul Surabaya 2013.

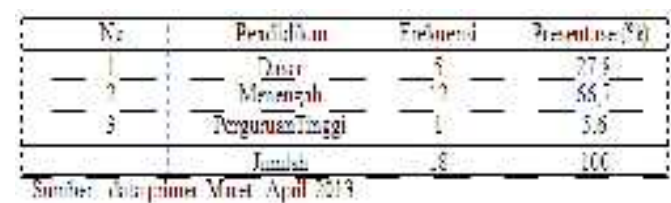

Berdasarkan tabel 5.2 dapat menunjukan dari 18 responden sebagian besar $(66,7 \%)$ berpendidikan menengah atas.

3) Karakteristrik responden menurut pekerjaanya.

Tabel 5.3 Distribusi frekuensi responden menurut pekerjaaanya di BPS ASKI Pakis Sido Kumpul Surabaya 2013.

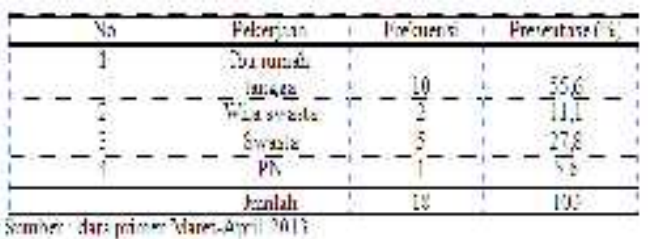

Berdasarkan tabel 5.3 dapat menunjukan dari 18 responden sebagian besar $(55,6 \%)$ pekerjaanya adalah ibu rumah tangga.

4) Karakteristik responden terhadap pantang makanan

Tabel 5.4 Distribusi frekuensi responden terhadap pantang makanan di BPS ASKI Pakis

Sido Kumpul Surabaya 2013.

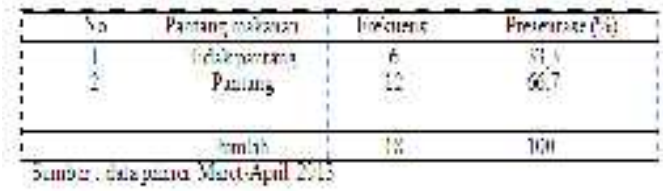

Berdasarkan tabel 5.4 dapat menunujukan dari 18 responden sebagian besar $(66,7 \%)$ pantang terhadap makanan.

5) Karasteristik responden terhadap perawatan payudara.

Tabel 5.5 Distribusi frekuensi responden terhadap perawatan payudara di BPS ASKI Pakis Sido Kunpul Surabaya.

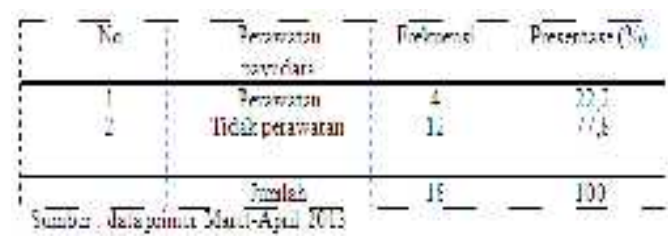

Berdasarkan tabel 5.5 menunjukan dari 18 responden hampir seluruhnya $(77,8 \%)$ tidak melakukan perawatan payudara. 
6) Kondisi psikologis ibu

Tabel 5.6 Distribusi Frekuensi responden menurut kondisi psikologis ibu di BPS ASKI Pakis Sido Kumpul Surabaya.

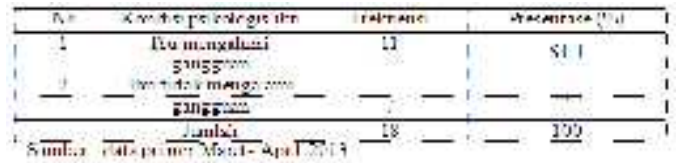

Berdasarkan tabel 5.6 dapat menunjukkan dari 18 responden menunjukan sebagian besar $(61,1 \%)$ ibu mengalami gangguan psikologis.

7) Kelancaran produksi ASI

Tabel 5.7 Distribusi frekuensi responden menurut kelancaran produksi ASI di BPS ASKI di Pakis Sido Kumpul Surabaya.

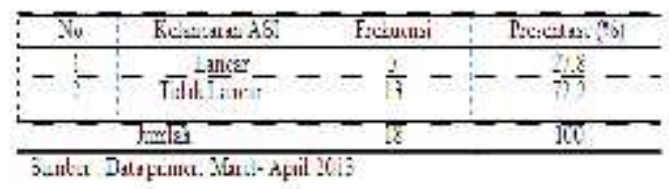

Berdasarkan tabel 5.7 dapat menunjukan dari 18 responden sebagian besar (72,2\%) ketidaklancaran pada ASI.

8) Hubungan kondisi psikologis ibu dengan kelancaran produksi ASI di BPS ASKI Pakis Sido Kumpul Surabaya.

Data tentang kondisi psikologis ibu dan kelancaran produksi ASI di BPS ASKI Pakis Sido Kumpul Surabaya seperti yang terlihat di tabel 5.8

Tabel 5.8 Tabulasi silang antara hubungan kondisi psikologis ibu dengan kelanncaran produksi ASI di BPS Pakis Sido Kumpul Surabaya.

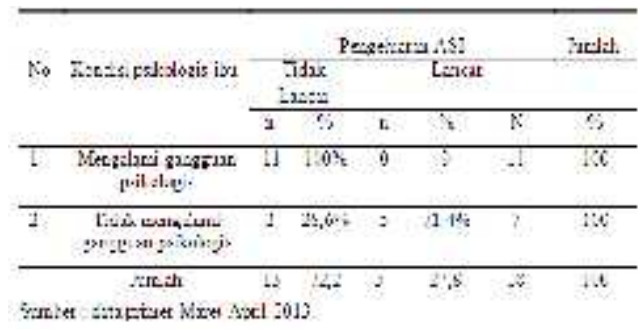

Berdasarkan tabel $\quad 5.8$ menunjukkan bahwa dari 11 reponden ibu yang mengalami gangguan psikologis seluruhnya (100\%) pengeluaran ASInya tidak lancar. Sedangkan dari 7 responden ibu tidak mengalami gangguan psikologis sebagian besar $(71,4)$ pengeluaran ASInya lancar.

Hasil uji korelasi statistik ChiSquare didapatkan $\rho=0,001$ akan tetapi tabulasi silang tidak memenuhi uji ChiSquare karena ada dua kolom yang tidak memenuhi syarat jadi uji yang digunakan adalah uji Fisher,s Exact Test didapatkan $=0,002$ berarti < 0,05 maka $\mathrm{H} 0$ ditolak yang berarti ada hubungan antara kondisi psikologis ibu dengan kelancaran produksi ASI di BPS ASKI pakis Sido Kumpul Surabaya.

\section{PEMBAHASAN}

1) Kondisi psikologis

Berdasarkan tabel 5.6 menunjukan dari 18 responden, sebagian besar $(61,1 \%)$ ibu mengalami gangguan psikologis. Terjadinya gangguan psikologis pada ibu adalah dipengaruhi oleh beberapa faktor, diantaranya responden yang diambil $100 \%$ ibu primipara sehinga terlihat pada penelitian seorang ibu cemas dan panik mendengar bayinya sedang menangis, ibu kebingungan karena masih baru pertama menghadapi situasi yang seperti itu dan itu menjadi faktor kesiapan ibu memasuki fase baru menjadi seorang ibu, dalam kondisi baru ibu memerlukan kesiapan dan kematangan dalam menerima pengalaman baru dalam hidupnya yaitu menjadi seorang ibu atau orang tua dari bayi yang baru dilahirkanya. Menurut Nirwana, B, N (2011) pada ibu pasca melahirkan khususnya pada ibu primipara dalam kondisi dimana memasuki fase baru, memerlukan banyak penyesuaian yang signifikan setelah kedatangan bayi baru.

Adapun faktor yang mempengaruhi kondisi psikologis ibu, pertama faktor umur. Berdasarkan tabel 5.1 menunjukan dari 18 responden sebagian besar $(66,7 \%)$ ibu berumur 20 23 tahun. Umur 20-35 tahun juga 
mengalami gangguan psikologis dikarenakan ini adalah pengalaman pertama pada ibu primipara khususnya memasuki fase baru menjadi seorang ibu. Meskipun pada umur 20-35 dianggap umur yang pas dalam bereproduksi.

Tetapi hasil pengamatan penelelitin umur sebagian besar pada umur 20-25 yang termasuk dalam kriteria muda sehingga Ibu masih keliahatan takut, gugup serta gelisah, banyak ibu yang mengeluh saat bayinya menangis karena ibu kebingungan bagaimana caranya agar bayi tidak menangis lagi. Pada dasarnya dengan bertambahnya umur ibu, dapat menambah pengalaman ibu dimana pengalaman juga bisa diperoleh dari diri sendiri maupun dari orang lain, dengan begitu ibu dapat memperoleh pengetahuan atau pengalaman baru. Hal tersebut sesuai teori Notoatmodjo (2003) bahwa pengalaman itu adalah suatu cara untuk memperoleh kebenaran, oleh sebab itu pengalaman pribadi ibu juga dapat digunakan untuk memperoleh pengetahuan baru dalam hal baru yang nantinya dijadikan pembelajaran yang dapat berdampak pada kondisi psikologis yang lebih baik.

Faktor kedua yang mempengaruhi kondisi psikologis ibu adalah pendidikan. Berdasarkan tabel 5.2 menunjukan dari 18 responden sebagian besar $(66,7 \%)$ mempunyai jenjang menengah atas. Hal ini menunjukan meskipun pada tingkat pendidikanya menengah tidak semua kondisi dan kesiapan secara matang, karena pada jenjang ini sebagian besar masih terlihat seperti kematangan psikologis dan banyak hal yang kurang diketahui dalam kondisi setelah kelahiran. Banyak ibu yang tidak tahu bagaimana cara menyusui dan mengendong bayi. Faktor pendidikan mempengaruhi pada perilaku seseorang, yang berpendidikan lebih tinggi akan lebih tahu bagamana cara menyesuaikan diri terhadap penyesuaian masuk ke fase baru. Pendapat Adinda (2006) semakin tinggi tingkat pendidikan ibu semakin muda menerima informasi yang disampaikan oleh tenaga kesehatan atau orang lain maupun dari media masa sehingga semakin tinggi pendidikan seeorang semakin matang dan lebih jauh untuk berfikir sesuatu yang baik buat dirinya dan akan berdampak pada kondisi psikologis dirinya yang lebih baik dalam menyiapkan kematangan dalam proses berfikir kedepanya.

Faktor yang ketiga yang dapat mempengaruhi kondisi psikologis ibu adalah pekerjaan pada tabel 5.3 didapatkan sebagian besar $(55,6 \%)$ ibu tidak bekerja. Ibu rumah tangga atau wanita tidak berkerja biasanya kurang mendapat informasi yang terbaru khususnya tentang kesehatan kerena ibu tersebut hanya berinteraksi dengan orang dilingkungan rumahnya saja. Hal ini dapat berpengaruh terhadap kondisi psikologis ibu, sebagai mana bermula dari berinteraksi seseorang bisa menambah pengetahuan dijadikan sebagai pembelajaran untuk menghadapi kondisi ibu yang membutuhkan kesiapan dalam menjalaninya, yaitu kesiapan ibu dalam memasuki fase baru menjadi seoeang ibu. Seseorang yang sering berinteraksi dengan orang di lingkungan kerjanya yang lebih mendapatkan informasi yang lebih luas dan dapat bertukar pikiran, pengetahuannya akan bertambah banyak. Menurut Notoadmodjo (2007), seorang yang memiliki pekerjaan dengan informasi yang lebih luas terdapat kecenderungan mempunyai pengetahuan yang lebih baik dan dengan berkerja seseorang dapat berbuat sesuatu yang bernilai, bermanfaat, dan memperoleh berbagai pengalaman yang lebih luas sehingga informasi yang di peroleh lebih banyak.

2) Produksi ASI

Berdasarkan tabel 5.7 menunjukan bahwa dari 18 responden sebagian besar $(72,2 \%)$ kelancaran ASI pada ibu pasca melahirkan tidak lancar. Untuk memproduksi ASI yang baik, maka kondisi ibu harus dipersiapkan karena 
dalam memproduksi ASI dipengaruhi banyak faktor diantaranya perlunya mempersiapkan kondisi psikologis yang baik untuk kelancaran prosuksi ASI. Kelancaran produksi ASI dipengaruhi oleh beberapa faktor yaitu faktor nutrisi, perawatan payudara, isapan dan frekuensi menyusui, sosial budaya dan faktor psikologis (Nur, Khasanah, 2011).

Faktor nutrisi dapat mempengaruhi kelancaran produksi ASI, berdasarkan tabel 5.4 menunjukan sebagian besar( $66,7 \%$ ) ibu pantang terhadap makanan ada beberapa makanan yang dianggap pantang untuk dimakan misalnya ayam dan ikan laut, masyarakat yang kurang pengetahuanya, menganggap ayam dan ikan laut dapat menyebabkan ASI berbau amis sehinga anak tidak mau menyusui yang akan mengakibatkan ASI tidak lancar, padahal ayam dan ikan laut merupakan salah satu sumber protein yang dibutuhkan ibu pasca melahirkan. Makanan yang dikonsumsi ibu menyusui sangat berpengaruh terhadap produksi ASI. Apabila makanan yang ibu makan mengandung cukup protein dan pola makan teratur, maka produksi ASI akan berjalan dengan lancar. Dan apabila ibu sedang menyusui bayinya tidak mendapat tambahan makanan, maka akan terjadi gangguan pada produksi ASI. Hal ini sesuai dengan teori Kristiyanasari, (2011) produksi ASI sangat dipengaruhi oleh makanan ibu, apabila makanan ibu cukup gizi terutama makanan tinggi protein akan mempelancar produksi ASI.

Faktor perawatan payudara juga dapat mempengaruhi kelancaran produksi ASI, berdasarkan tabel 5.5 menunjukan dari 18 responden hampir seluruhnya $(77,8 \%)$ tidak melakukan perawatan payudara, sedangkan perawatan payudara seharusnya juga harus dilakukan ibu pasca melahirkan untuk menghindari tersumbatnya saluran susu karena kotor pada puting susu sehingga ASI keluarnya tidak lancar, dan apabila ASI tidak bisa keluar dapat terjadi pembengkakan pada payudara. Menurut Nur khasana,(2012) perawatan payudara sangat penting dalam kelancaran ASI, apabila ibu melakukan perawatan payudara dengan benar dan teratur dapat merangsang produksi ASI.

3) Hubungan antara kondisi psikologis ibu dengan kelancaran produksi ASI

Hasil uji Fisher's Exact Test di dapatkan $=0,002$ berarti $<0,005$ maka Ho ditolak yang berarti ada hubungan antara kondisi psikologis ibu dengan kelancaran produksi ASI. Kondisi psikologis ibu yang baik dapat berdampak baik bagi ibu untuk kelancaran produksi ASI. keadaan psikologis ibu yang baik akan mermotifasi untuk menyusui bayinya sehingga hormon yang berperan pada produksi ASI akan meningkat karena produksi ASI dimulai dari proses menyusui akan merangsang produksi ASI, sesuai dengan teori Dewi (2011) semakin sering ibu menyusui semakin banyak ASI yang diproduksi, karena dari proses menyusui akan merangsang hormon yang berperan dalam produksi ASI.

Menurut Dewi, (2011) kondisi psikologis ibu dapat mempengaruhi produksi ASI karena butuh penyesuaian pada ibu pasca melahirkan khususnya ibu primipara dalam memasuki fase baru dan pegalaman baru menjadi orang tua juga tidaklah mudah dan tidaklah selalu menjadi hal yang menyenangkan bagi setiap wanita sehingga dapat mempengaruhi kondisi ibu dan berdampak pada kelancaran produksi ASI. Oleh karena itu, dalam hal ini tenaga kesehatan memegang peranan penting untuk tetap meningkatkan pelayanan kesehatan yang menyeluruh dan bermutu dengan bekal ilmu dan ketrampilan yang dimiliki sehingga di harapkan dapat memberi penngetahuan atau informasi untuk menyiapkan kondisi psikologis ibu agar ibu lancar dalam memberikan ASI atau menyusui bayi pertama kali sehingga bayi mendapatkan ASI dan ibu yang sering menyusui akan 
membantu proses produksi ASI sehingga ASI keluar lancar. Memberikan ASI juga merupakan keuntungan, semua keuntungan ini tidak hanya dirasakan oleh bayi, tetapi juga dirasakan oleh ibu, lingkungan bahkan negara.

\section{SIMPULAN}

1. Ibu pasca melahirkan di BPS ASKI di Pakis Sido Kumpul Surabaya sebagian besar mengalami gangguan psikologis ibu.

2. Ibu pasca melahirkan di BPS ASKI Pakis Sido Kumpul Surabaya sebagian besar pengeluaran ASInya tidak lancar.

3. Ada hubungan kondisi psikologis ibu dengan kelancaran produksi ASI pada ibu pasca melahirkan di BPS ASKI Pakis Sido Kumpul Surabaya.

\section{DAFTAR RUJUKAN}

Arikunto, Suharsimi. 2006. Prosedur Penelitian Suatu Pendekatan Praktik. Jakarta: Rineka Cipta

Arikunto, Suharsimi. 2010. Prosedur Penelitian Suatu Pendekatan Praktik. Jakarta: Rineka Cipta.

Bahiyatun. 2009. Buku Ajar Bidan Psikologi Ibu dan Anak. Jakarta: EGC Bobak. 2004. Buku Ajar Keperawatan. Maternitas. Jakarta : EGC

Dep Kes RI. 2005. Manajemen Laktasi. Jakarta. Pusdiknakes

Dewi, Vivian. 2011. Asuhan Kebidanan Pada Ibu Nifas. Jakarta: Salemba Medika

Februhartanty, J. 2009. ASI : Dari Ayah Untuk Ibu Dan Bayi. Jakarta Selatan: Semesta Medika

Iskandar SS. 2005. Depresi Pasca Kehamilan (Postpartum Blues) http//wwwmitrakeluarga.net diakses tanggal 20 November 2012

Khasana, Nur. 2011. ASI Atau Susu Formula. Jogjakarta, Flas book
Kodrat, Laksono. 2010. Dahsyatnya

ASI \& Laktsi. Jogjakarta, Media

Baca Mansur, Herawati . 2009.

Psikologi Ibu Dan Anak Untuk

Kebidanan. Malang:

Salemba Medika

Marshal. 2004. Mengatasi Depresi Pasca Melahirkan. Jakarta: Arcan

Nirwana, A. B, 2011. Psikologi Ibu, Bayi

Dan Anak: Yogyakarta. Nuha Medika

Nursalam. 2010. Konsep \& Penerapan Metologi Ilmu Keperawatan.

Jakarta: Salemba Medika

Suririnah. 2006. Buku Pintar Kehamilan dan Persalinan.

Jakarta, Gramedia

Pustaka Utama Nursalam. 2008.

Saryono. Pramitasari. Roischa. 2009.

Perawatan Payudara. Yogyakarta, Nurha Medika 